\title{
Does it matter where IT workers are located?
}

\author{
Elsie Echeverri-Carroll, Sofia G Ayala \\ IC ${ }^{2}$ Institute, The University of Texas at Austin, 2815 San Gabriel, Austin, TX 78705, USA; \\ e-mail: e.carroll@mail.utexas.edu, Sofia_ayala@mail.utexas.edu
}

\section{Mayuresh Kshetramade}

Affinnova Inc., 52 Second Avenue, Waltham, MA 02451, USA

\section{Priyanka Murthy}

Transfer Pricing, Deloitte Tax LLP, 111 South Wacker Drive, Chicago, IL 60606-430, USA

Received June 2004; in revised form 31 July 2006

\begin{abstract}
The predominant view in the literature is that cities affect labor productivity because spatial proximity facilitates the transfer of ideas which make workers more productive. We also anticipate that information technology, or IT (both equipment and labor), by facilitating human communication and speeding up the flow of ideas and data, also contributes to enhancing the productivity of workers within cities. Thus, workers will be more productive in cities with a large endowment of these two factors of production. The objective of this paper is twofold. First, it describes the spatial characteristics of IT workers in the United States. Second, it tests the hypothesis that in cities with a higher endowment of IT workers wages (a proxy for productivity) would be higher after controlling for the characteristics of individual workers and city-specific characteristics that also affect wages. Using data from the 2000 US Census of Population (5\% PUMS), we find evidence of a wage premium, especially for college-educated workers, associated with living in a city that has a large concentration of IT workers. On the basis of our findings, we propose to move the discussion on the future of cities from the effect of IT equipment on face-to-face communication to the impact on cities of losing IT workers.
\end{abstract}

\section{Introduction}

According to Digital Economy 2002 (DE2002) published by the US Department of Commerce, the level of US real investment in IT processing equipment (computers, computer peripherals, and telecommunications) soared at a $20 \%$ annual rate between 1995 and 2000 (USDC, 2002). Even though real IT investment dropped by $10.7 \%$ over the course of 2001, it remained higher than at any time prior to early 2000 . The steep growth in IT investment during this period translated into a rapidly growing net capital stock of IT equipment and software as well as rapid growth of employment in IT occupations. ${ }^{(1)}$ When firms across the economy integrate IT into their operations, there is a substantial demand for workers with IT skills. According to Mann (2003), throughout the economic boom of the 1990s, investment in IT propelled job growth for workers with IT skills to twice the rate of job growth in the overall economy.

Employment opportunities for workers in IT occupations (or IT workers) opened across all industries. As Cooke (2002) points out, IT workers design, manufacture, operate, maintain, and repair IT products and provide related services across all industries, not just in IT-producing industries. For instance, a computer programmer might work in financial services or the retail trade as well as in IT-producing industries such as communication equipment, communication services, or hardware, software, and related computer services.

(1) Occupations change gradually as technology creates new job categories and eliminates old ones. The Bureau of Labor Statistics revises the Standard Occupational Classification (SOC) to reflect these changes. Because of changes in SOC categories, historical trends on US employment in IT occupations are very difficult to build. 
How IT equipment and labor contribute to the productivity of plants, industries, and the country has been a key question in the literature and among policymakers and managers. Most of the studies at the plant and industry level use a production function approach to test the relationship between the level of output and the level of various inputs, including IT-related and non-IT-related capital and labor. These studies seek to answer two questions. (1) Has the absorption of IT-intensive equipment and techniques into the production process increased output at the plant and at the industry level? (More specifically, have computers enabled the production of more output, of either old or new products, while using fewer inputs?) (2) Has the increase in the number of workers who generate, use, or maintain information products increased output at the plant and at the industry level?

Most previous studies provide evidence of a positive contribution of IT equipment to the productivity of workers, establishments, and industries. These studies find that workers who use computers are more productive than those who do not (Autor et al, 1998; Wheeler, 2005a). For instance, using data for the years 1984 and 1989 for the United States, Krueger (1993) found that workers who used computers earned about $10 \%-20 \%$ more than workers who did not. Valleta and MacDonald's (2004) analysis of data for the United States from 1984 to 2001 shows that the return to computer use reached a peak in 1993 , with a $24.2 \%$ wage advantage over otherwise similar workers. Although all workers using computers have a wage premium over those not using computers, the wage premium is proportional to the worker's years of education. As noted by Valletta and MacDonald (2004), advances in computer technology have enabled increasingly sophisticated applications that require complex and evaluative skills; thus, a leading reason to attend college is to acquire such skills.

Studies at the company level also find a positive association between the use of information technologies (for example, computers), and various measures of productivity (Applegate et al, 1988; Black and Lynch, 2001; Bresnahan et al, 2002; Brynjolfsson and Hitt, 1996; Doms et al, 1997). Similar positive results have been found at the industry level (Autor et al, 1998; Card and Dinardo, 2002). However, proof of a positive relationship between IT capital and output for the country as a whole has been elusive. As noted by Brynjolfsson and Hitt (2003), one explanation is that IT spending may lead to an increase in product quality or variety that may increase output at the firm level but will tend to be overlooked in aggregate statistics.

Published research on the productivity of IT workers is scarce (Gubarxani et al, 1997; Hitt and Brynjolfsson, 1995; Lichtenberg, 1993; USDC, 1997). This is quite surprising given the current debate on the effect that the possible relocation of IT workers to countries like India and China might have on the US economy. By ignoring the spatial consequences of the relocation of IT functions, this debate implicitly assumes that IT workers are homogeneously dispersed and that therefore all cities will be equally affected by the offshoring of IT workers.

In a recent paper Wheeler (2005b) analyzed the effect of computer usage in cities. But, to our knowledge, no previous study has focused on the effects of IT workers in cities. More important, no previous study has addressed the following question: under what conditions will the offshoring of IT workers affect US cities? We anticipate that the offshoring of IT workers would have a significant effect on US cities under two conditions, described below.

The offshoring of IT workers will have a large impact on some US cities if the distribution of IT workers across cities is skewed-that is, if IT workers are strongly concentrated in only a few cities. Because IT workers in such cities would account for a large proportion of the local labor force, the offshoring of IT workers would have a significant effect on the economic performance of these cities. If, as expected, these cities 
are also the locus of a large percentage of the country's economy activity, the effect could have a strong impact on the national economy. In this regard, it is important to know: are IT workers concentrated in relatively few cities?

The offshoring of IT workers will also have a large impact on some US cities if there are local productivity-enhancing effects associated with the spatial agglomeration of IT workers. A key question in this regard is: do workers located in cities with a large agglomeration of IT workers have higher wages (and presumably higher productivity) than those living in cities with a low concentration of IT workers? If this is the case, we would anticipate that changes in the international division of IT workers in favor of India or China could have potentially negative effects on the productivity of US workers, especially those working in cities with the largest concentration of IT workers. But why would workers located in IT-intensive cities receive higher wages? One can speculate that some positive effects on the productivity (and presumably wages) of local workers come from knowledge spillovers emerging from high-skilled IT workers as well as from a smoothly-running IT infrastructure thanks to the work of moderately skilled IT workers.

The rest of the paper is divided as follows. In section 2 we analyze the geographical distribution of IT workers across US metropolitan areas. In section 3 we review the literature on the effects of IT on cities and we propose to refocus the analysis from the possible effects of IT equipment to the potential effects of changes in the international division of IT workers on the future of US cities. In section 4 we use hierarchical linear models to test for the existence of localized economies associated with IT workers. In section 5, we discuss some policy recommendations emerging from this study.

\section{The geography of IT workers}

In this section, we answer three questions. (1) What US cities are relatively IT worker intensive? (2) Do IT workers tend to concentrate in relatively few cities? (3) Do IT workers account for a large proportion of the local labor force?

According to DE2002, IT occupations (see appendix table A1 for a list of IT occupations by skill levels) included 6.65 million workers (USDC, 2002). More than half (3.8 million) of the workers with IT occupations were in jobs that generally need at least an associate degree. Computer and software engineers and computer-hardware engineers are among the highest skilled IT occupations. In 2000, about $25 \%$ of IT workers (1.6 million) were employed in moderately skilled occupations - jobs requiring long-term on-the-job training, related work experience, or postsecondary vocational training. Such jobs include data-entry keyers and office-machine repairers. Only 19\% (1.25 million) were employed in low-skilled IT occupations, such as switchboard operators.

To answer the questions posed at the beginning of this section, we used a sample of 1.4 million full-time male and female workers from the 2000 Census of Population who lived in the 100 largest metropolitan areas in the United States. ${ }^{(2)}$ Using the same definition for IT occupations as in DE2002, we find that $6.9 \%$ of total male and female full-time workers are in IT occupations in our sample (95955 workers). Moreover, using the same breakdown as in DE2002 by skill levels, we find that $63.8 \%$ of workers in our sample $(61215)$ were in high-skilled IT occupations, while only $22.9 \%$ (21942) and 13.3\% (12798) were in moderately skilled and low-skilled IT occupations, respectively.

(2) We focus only on full-time workers because they have a larger attachment to the labor market than do part-time workers, so we can use the same sample to estimate our wage equations in the next section. A sample with a strong attachment to the labor market minimizes problems of selection bias and therefore simplifies the statistical analysis. However, we expect that part-time workers have similar location trends to those of full-time workers. 
We observed that, on average, workers in IT occupations have higher hourly wages (\$23) than workers in non-IT occupations (\$18). College-educated workers account for a larger share of workers in the group of IT workers $(45 \%)$ than in the group of non-IT workers $(30 \%)$. Moreover, whereas $64 \%$ of IT workers are males, only $55 \%$ of the non-IT workers are males.

Do IT workers tend to concentrate in relatively few cities? The answer is yes. Figure 1, which illustrates the percentage distribution of IT workers by quintiles, shows that $54.2 \%$ of the IT workers in our sample are concentrated in the top 20 cities, and only $3.8 \%$ of IT workers are in the bottom 20 .

Which US cities are more IT worker intensive? The relative concentration of IT employment in metros could be determined by the use of location quotients (LQs). ${ }^{(3)}$ LQs compare IT employment as a share of total employment in a metro relative to the same calculation in the total sample of 100 metropolitan statistical areas (MSAs):

$$
\mathrm{LQ}_{\text {city }}=\frac{\mathrm{IT}_{\text {employment-city }}}{\text { total }_{\text {employment-city }}} / \frac{\mathrm{IT}_{\text {employment-100MSAs }}}{\text { total }_{\text {employment-100MSAs }}} \text {. }
$$

Cities with an LQ $>1$ are IT employment intensive, which simply means that these cities have a proportion of employment in IT occupations above the average for the whole sample of 100 metros. The problems with using the LQ to rank cities, as extensively discussed by DeVol (1999), is that LQs do not adjust for the size of a metro area relative to others. Thus, in relatively small metros, a few large plants employing a large proportion of IT workers can result in a large LQ. An example will better illustrate this problem. When we use the LQ to rank our 100 MSAs by their relative intensiveness of IT workers, Omaha MSA (Nebraska-Iowa) ranks 12 and Monmouth - Ocean MSA (New Jersey) ranks 16 - both above San Diego MSA (California), a recognized high-tech hub that ranks 25 . In this case, a few large IT employers, such as First Data Corporation (owner of Western Union and a provider of electronic commerce and payment services) and First Data Resources (a third-contract processor for bank-card transactions), account for a large proportion of the local labor market in Omaha, a city identified as the blue-collar capital of the information economy - not a vibrant hub for high-skilled and moderately-skilled IT workers. Similarly, a few large companies such as AT\&T, Lucent Technologies, and Telecordia (formerly Bellcore)

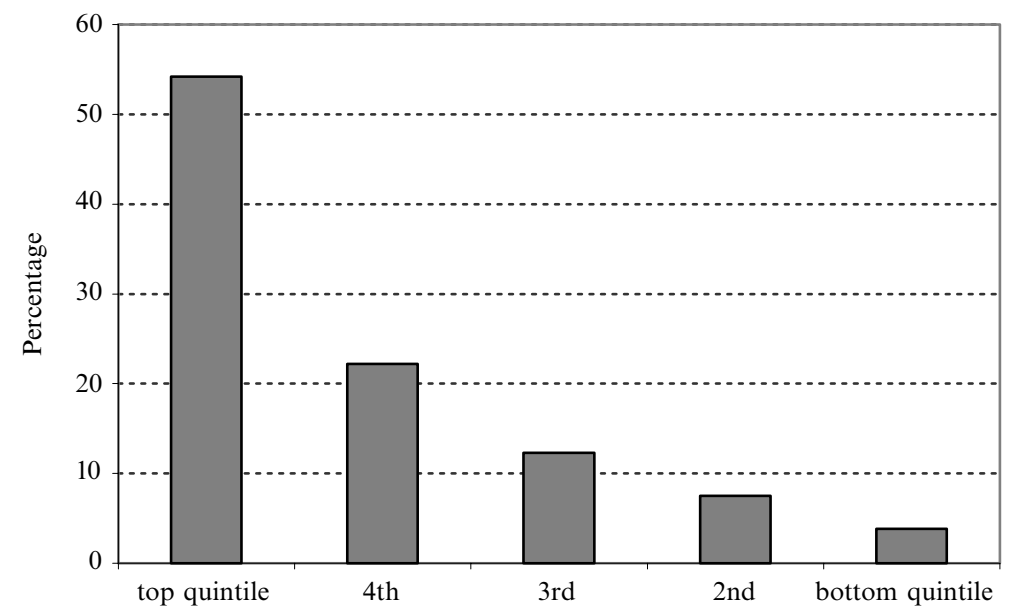

Figure 1. Percentage of IT workers by quintile groups of metropolitan areas.

(3) The terms 'city', 'metro', and 'metropolitan area' are used interchangeably throughout this study. 
account for a relatively large proportion of total employment in Monmouth; thus, even though it is a relatively unimportant high-tech metro at the national level, Monmouth scores very high in the ranking.

To correct for this problem, DeVol (1999) proposed weighting the LQ with a second component. In our case, the second component captures the city's level of IT employment relative to the total IT employment in the 100 metros. Similar to that of the Milken Institute (DeVol, 1999), our index of IT intensity has two components. The first represents the IT LQ that compares the proportion of a city's IT employment (percentage of jobs) to the proportion of IT employment in the 100 metropolitan areas in our sample. The second component captures the city's level of IT employment (number of jobs) relative to the total IT employment in the 100 metro areas. In short, this IT-agglomeration index is a weighted LQ in which the weight measures the relative importance of the city's IT employment in US IT employment:

$$
\text { IT index } x_{\text {city }}=\operatorname{LQ}_{\text {city }}\left(\frac{\mathrm{IT}_{\text {employment-city }}}{\mathrm{IT}_{\text {employment-100MSAs }}}\right) 100 \text {. }
$$

The ranking of 100 MSAs used in our analysis according to their level of IT agglomeration is presented in appendix table A2. We find a large variance in the spatial agglomeration of IT workers: the IT-agglomeration index varies from 8.8 to 0.02. As expected, cities with a large concentration of the economic and political activities in the country have a large relative concentration of IT workers. Washington, DC (8.8), San Jose (7.8), and Chicago (4.7) are the top three. In contrast, cities with a relatively low participation in US economic activity, such as Youngstown-Warren (Ohio) (0.07) and McAllen-Edinburgh-Mission (Texas) (0.02), are at the bottom of the ranking.

How large is the supply of IT workers within the local market? Appendix table A3 shows the percentage of workers in IT occupations in the 100 metros. The mean of the proportion of IT workers for all 100 MSAs is $6.4 \%$, indicating that for most cities the percentage of full-time IT workers is relatively small. However, in some cities, IT workers account for a larger proportion of the local market: for example, 18\% in San Jose; about 12\% in Middlesex - Somerset - Hunterdon (New Jersey); 11\% in Washington, DC; and about $10 \%$ in Raleigh-Durham - Chapel Hill (North Carolina), Austin-San Marcos (Texas), Oakland (California), and San Francisco (California).

If IT workers (skilled and unskilled) account for only $4 \%$ of all workers (full-time and part-time) and a slightly larger proportion (6\%) of full-time workers, why should we worry about losing such a small percentage of the workforce to countries such as China and India? One answer could be that, although the proportion of IT workers in the US economy is relatively small, this is not the case for some of the most economically vibrant cities in the country. As indicated, IT workers comprise $18 \%$ of the local labor force in San Jose; more specifically, high-skilled IT workers comprise 15\%. Also, as noted, the spatial distribution of IT workers is skewed toward a relatively small group of the most vibrant economic and political metropolises. Based on these findings, one could anticipate that a possible relocation of IT workers to foreign countries could have significant and deleterious effects on these cities. How is this issue addressed in the spatial literature? We review this literature in the next section.

\section{Information technology and the future of cities}

Mann (2003) introduced the concept of the 'information technology package' (hardware, software, and business services). The concept recognizes that making IT hardware to fit an organization comes in part from the increased dominance of software and IT services (IT workers). During the 1990s the pattern of spending on the components of 
IT packages changed in the United States: the market for software, and particularly IT services, increased dramatically. We propose that an analysis of the effect of information technology on the future of cities needs to take into consideration both IT hardware and IT human capital.

\subsection{Computers and cities}

Will electronic networks substitute for the handshakes through which trust and understanding are developed in the transmission of complex uncodifiable messages? At the root of this kind of question is the fear that barriers and borders will break down as new ideas and information travel faster to remote locations, and that, as anticipated by Cairncross (1997) in his book The Death of Distance, cities will become centers of entertainment and culture, not of work.

Since the introduction of the IBM PC in 1981, desktop computers have become a standard fixture in most workplaces. Although computers were used first to improve the efficiency of workers within the boundaries of the firm, they rapidly became an efficient tool to move data and information across firms. This process was facilitated by the development of a wide variety of electronic communication networks that strengthened communication systems with computer technology. These include local area networks (for example, to link workers together in an office); wide area networks (for example, to link the workforce of a large organization across multiple locations and/or multiple organizations); and the Internet (which potentially could link all people and all organizations together in a global communication network).

Advances in computer networks have facilitated the globalization of $\mathrm{R} \& \mathrm{D}$, a process usually associated with the need to transfer complex ideas. Indeed, there is a lot of evidence of the globalization of R\&D. One of the most complete sources of data on R\&D collaborations is the MERIT - CATI database developed and maintained by John Hagedoorn and other researchers at MERIT University in Maastricht, Netherlands. ${ }^{(4)}$ Hagedoorn (2002) analyzed world interfirm R\&D partnering data for the period 1960-98 from the CATI databank, finding growth (with short periods of decline) of interfirm R\&D partnerships since $1980 .{ }^{(5)}$ Many of these $R \& D$ collaborative agreements were international. Indeed, the share of domestic interfirm collaboration (within the United States) recorded in CATI as occurring during the 1970s and 1980s was only about $35 \%$ of total collaborations.

Data on the location pattern of innovative activities of multinational firms also show a clear pattern of the globalization of R\&D. According to data from the National Science Foundation's industrial R\&D survey (NSF, 2001), R\&D performed abroad by foreign affiliates of US parent companies (or overseas $\mathrm{R} \& \mathrm{D}$ spending) increased from $\$ 3$ billion in 1985 to $\$ 17$ billion in 1999. Moreover, as figure 2 illustrates, overseas $R \& D$ of US companies shows an upward trend that became steeper in the 1990s. But it is not only US companies that are increasingly investing in $R \& D$ overseas: $R \& D$ spending by US affiliates of foreign companies in the United States (or foreign $R \& D$ spending) increased from \$1.5 billion in 1980 to \$22 billion in 1998 (NSF, 2002).

(4) The Cooperative Agreements and Technology Indicators (CATI) databank contains information, collected since 1960, on thousands of technology-related interfirm partnerships. Only those interfirm agreements that contain some arrangement for transferring technology or joint research are collected in this database (see Hagedoorn, 2002, appendix A).

(5) R\&D partnerships are defined as the specific set of different modes of interfirm collaboration where two or more firms (which remain independent economic agents and organizations) share some of their $R \& D$ activities. These $R \& D$ partnerships primarily conform to one of two categories: contractual partnerships (such as joint $\mathrm{R} \& \mathrm{D}$ pacts and joint-development agreements) and equity-based joint ventures. 


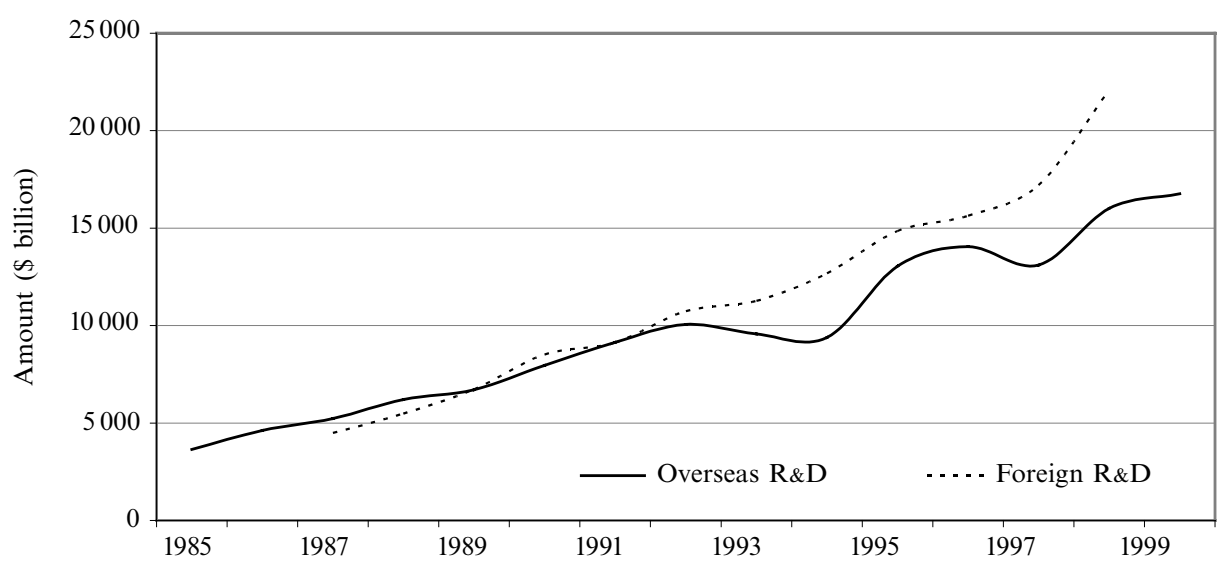

Figure 2. Amount spent on overseas $R \& D$ by US firms and on foreign $R \& D$ in the United States, 1985 - 99 (source: NSF, 2002).

Ozer (2000) notes that computer-mediated communication is contributing to changes in the geography of $\mathrm{R} \& \mathrm{D}$ activities by allowing virtual teams of experts to conduct $\mathrm{R} \& \mathrm{D}$ activities across geographical boundaries. He cites the case of several companies which, faced with the challenge of effectively managing new product teams across space and time zones, are increasingly using IT in coordinating new product development activities. Does this mean that the communication of complex ideas (associated with $\mathrm{R} \& \mathrm{D})$ is decreasing its dependence on face-to-face contacts?

Many studies note that, despite advances in electronic communication in the work environment, only routine functions that can be codified can be transferred electronically: face-to-face interactions continue to be important in the production and distribution of new or complex ideas (Audretsch and Feldman, 1996; Goodchild, 2001; Leamer and Storper, 2001; Rallet and Torre, 1998). Virtual teams need to build a relationship, often through face-to-face meetings, before they can effectively collaborate electronically (Lynne and Marcus, 1997; McDermott, 1999). As McDermott (1999) points out, if a group of people do not already share knowledge, even if they have plenty of contact and understand what insights and information will be useful to each other, then IT is not likely to create that collaboration. Lavoie (2004) notes that the key to the knowledge economy is not primarily a matter of getting access to quantities of data: rather, it is the revolution in ways of working with, and working together with, the data.

Knowledge is different from information. Knowledge belongs to a community and circulates through communities; it is expanded through communities of practice and epistemic communities. Learning a practice involves becoming a member of a 'community of practice' and thereby understanding its work and its talk from the inside. Learning, from this point of view, is not simply a matter of acquiring information: it requires the development of the disposition, demeanor, and outlook of the practitioners. Wenger et al (2002, page 4) define communities of practice as "groups of people who share a concern, a set of problems, or a passion about a topic, and who deepen their knowledge and expertise in this area by interacting on an ongoing basis." The concept of communities of practice is broad: it involves groups of highly skilled workers, such as engineers designing a certain kind of electronic circuit, who find it useful to compare designs regularly and to discuss the intricacies of their esoteric specialty, but it also involves soccer moms and dads who take advantage of game times to share tips and insights about the subtle art of parenting (Wenger et al, 2002). 
On the other hand, the concept of epistemic communities is more restrictive as it refers exclusively to a network of professionals with recognized expertise and competence in a particular domain and authoritative claim to policy-relevant knowledge within that domain or issue area (Haas, 1992).

Storper and Venables (2004) introduced the concept of 'buzz cities' which result from the increasing importance of colocation of economic activities that involve the exchange of tacit knowledge or complex ideas. They observe that cities facilitate learning and are particularly attractive to highly talented young people who stand to gain large potential returns from learning. The hypothesis is therefore that knowledge 'rubs off' on people in places such as Silicon Valley or London. Moreover, the authors claim that people in a buzz environment should be highly productive. This is because individuals in a buzz environment interact and cooperate with other high-ability people, are well placed to communicate complex ideas with them, and are highly motivated. To be able to reap these benefits in full almost invariably requires colocation rather than occasional interludes of face-to-face contacts.

In sum, the question of whether computers will replace face-to-face communication and therefore threaten the existence of cities is passé. We now know that complex economic activities (such as R\&D), even as they become more global, will continue to depend on epistemic communities and on communities that are anchored in face-toface contacts. What is new and intriguing is whether companies will continue to buy IT labor services offshore and how this trend will affect the future of US cities. As Kotkin (2000, pages $6-7$ ), referring to spatial changes in the digital era, notes:

"the key rule grows from the realization that where information-processing companies, related services, and skilled professionals choose to locate will increasingly shape the geographic importance of future cities and communities" (emphasis added).

\subsection{IT workers and cities}

The traditional belief has been that the increasing usage of computers at work offers opportunities for high-skilled IT workers and risks for low-skilled IT workers. For the most part, the highest skilled IT workers have enjoyed strong demand for their services and above-average wages. In contrast, less-skilled IT workers (as well as non-IT workers) have faced the likelihood of being displaced by rapidly evolving technologies or by the decisions of local companies to source these IT skills abroad. However, a new round of globalization is starting to source abroad some high-skill jobs such as chip design, engineering, basic research, and even financial analysis. As Gereffi and Sturgeon (2004) explain, the first wave of global outsourcing began in the 1960s and 1970s with the exodus of production jobs in shoes, clothing, cheap electronics, and toys. After that, routine service work, like credit card receipt processing, airline reservations, and the writing of basic software code began to move offshore. Today, the computerization of work, the Internet, and high-speed private data networks have allowed a wide range of 'knowledge work' to become more footloose.

In this paper we tackle the question asked by policy makers and the media: can US cities lose these jobs and still prosper? There is a dearth of research on what role IT workers play in the economy of cities. This scarcity is not surprising. As mentioned above, most studies that analyze the impact of information technology on the productivity of workers, firms, and industries focus on the effect of IT equipment alone, in spite of strong evidence that productivity-enhancing effects depend on the successful use of IT, not just the accumulation of IT physical capital (Josefek and Kauffman, 1998).

In one of the few studies that measure the importance of IT staff to increases in productivity in firms, Brynjolfsson and Hitt (2003) found that a dollar spent on IT staff 
is associated with a marginal increase in output of $\$ 2.62$. They point out that the surprisingly high return to information-systems labor may reflect systematic differences in human capital, since IT staff are more likely to have more education than other workers. Comparing productivity gains across world regions, Daveri (2003) finds that the IT-using industries (not the IT-producing industries) contributed the bulk of productivity gains in the United States in the 1990s, and notes that despite the catching-up in IT diffusion by Europe and Japan in recent years, IT has so far delivered little in the way of aggregated productivity gains in these countries because they are still learning how to use this technology effectively.

We predict that workers living in a city with a large cluster of IT workers will be more productive than workers living in a city with a relatively small supply of these workers. As Chapple et al (2004) note, IT workers are helping firms across many sectors adapt to new technologies: using them to create new products and services, or to improve their production and marketing processes. While a large cluster of high-skilled IT workers could be a source of knowledge spillovers, middle-skilled and low-skilled IT workers guarantee that the existing IT systems are maintained more efficiently.

In the next section, we estimate a model that allows us to measure the relationship between the relative spatial clustering of IT workers and variations in average wages (a proxy for the productivity of workers) across cities.

\section{Methodology and empirical results}

Are there localization economies associated with the clustering of IT workers in a city? In other words, does the clustering of IT workers within a city have local wage effects? If so, are these effects similar for high-skilled workers (those with college education) and for low-skilled workers (those without a college degree)? In this section, we describe the model used to measure these effects, the data for individual workers and cities used to estimate the model, and the results from the model.

\subsection{Sample and data}

We use the 5\% sample of Public Use Microdata Sample (PUMS) of the 2000 Census of Population. In our sample, we include male and female workers with a strong attachment to the labor market (in particular, those aged 18-65 years) who are working full-time (at least 35 hours per week), are not self-employed or in the military, and have worked at least 14 weeks in the year previous to the census. Using those parameters, we got a sample of 1.4 million individuals residing in the largest 100 cities. We chose only the top 100 metros because $76 \%$ of the total urban population in the United States lived in these metro areas in 2000, and because including very small metropolitan areas would cause PUMS sample-size problems.

The MSA definition from the US Office of Management and Budget (OMB) must be matched with PUMS geographical areas. This is because census data use PUMS codes to define geographical areas that are different from those used by the OMB. In the matching process, one may have to exclude or include some counties in the OMB's definition of MSA because sometimes a single PUMS code for an area may consist of more than one county, or one county may be associated with many PUMS codes, depending on the population of that county.

At the individual level, the variable of interest is a binary variable that is equal to 1 if the worker does not have a college degree and 0 otherwise (for example, if the individual has a college degree). Most of the control variables for individual workers come from the census. The omitted broad occupational category in the wage equation is 'services'. 'Marital status' is 1 if the individual is married; 'sex' is 1 if the individual is female; 'race' is 1 if the individual is black; 'enrollment' is 1 if the individual is enrolled 
in school at the time of the census; 'health' is 1 if the individual has a personal healthcare limitation; 'high-tech' is 1 if the individual works in a high-tech industry; and 'children' is 1 if the individual has children under 18 years of age. ${ }^{(6)}$

Our city-level variables come from different sources. The variable of interest is the index of IT agglomeration in a city that we discussed in section 2 . We control for other variables that have been shown in previous research to affect variation of wages across cities. These variables are listed in table 1. Following Rauch (1993), we control for a city's average level of education and average level of experience with data from the 2000 Census of Population. Rauch (1993) finds empirical evidence that increasing the citywide average education level - a proxy for local knowledge spillovers - by one year raises an individual worker's wages by between $3 \%$ and $4 \%$ after controlling for the observable characteristics of workers and for other observable regional characteristics.

Table 1. Measures of metropolitan area labor-market structure (second-level variables).

Variable Data source Definition

Average level of education

Average level of experience

Climate score

Coastal region

Arts score

Population

Geographical regions (Northwest, Midwest, West, and South)
Places Rated Almanac, 2000

Places Rated Almanac, 2000

Weighted 5\% Public Use Microdata Sample of the 2000 Census of Population

Weighted 5\% Public Use Microdata Sample of the 2000 Census of Population

Places Rated Almanac, $2000^{\mathrm{a}}$

US Census Bureau, Census $2000(100 \%$ data $)$

5\% Public Use Microdata Sample of the 2000 Census of Population
Average level of education of fulltime workers, ages $18-65$ years, measured in years of schooling.

Average level of experience of fulltime workers, ages $18-65$ years, measured by age minus years of schooling minus six.

Composite score that averages four factors: winter mildness, summer mildness, seasonal affect, and hazardousness. (Score: lowest $=0$ to highest $=100$.)

Binary variable indicating whether the metropolitan area is proximal to a coast or the Great Lakes.

Composite score of the number of art museums, annual museum attendance, per capita museum attendance, annual ballet performances, touring artist bookings, opera performances, professional theater performances, and symphony performances.

(Score: lowest $=0$ to highest $=100$.)

Metropolitan Area population

Binary variable indicating the region where the metropolitan area is located.

a Savageau and D'Agostino (2000).

(6) We followed the US Department of Labor's definition of manufacturing and service high-tech industries (Hecker, 1999), as those with at least twice the US average of technology-oriented workers (TOW), where TOW are those in four SOCs: engineers; life and physical scientists; computer professionals and mathematicians (except actuaries); and engineering, computer, and scientific managers. 
In other studies it has also been found that workers are paid higher wages (and are presumably more productive) in cities with higher levels of human capital (Black and Henderson, 1999; Eaton and Eckstein, 1997; Glaeser and Mare, 1994; Rauch, 1993).

Regional wages also vary because of lumpiness in the regional supply of exogenous amenities, such as climate or physical geography (Rauch, 1993; Roback, 1982). One would, then, predict that wages would vary in cities in proportion to their stock of exogenous amenities (Black and Henderson, 1999; Eaton and Eckstein, 1997; Rauch, 1993). Following many previous studies, we assume that wages should be lower in a city with a mild climate, but that wages will be higher in cities with a port due to privileged access to gains from international trade (Rauch, 1993). ${ }^{(7)}$ A dummy variable for coastal location is set at 1 if an MSA borders an ocean or any of the Great Lakes, and 0 if not. Wages should also be higher in cities with a large accumulation of cultural activities. We use an arts score that is calculated based on the availability of cultural and artistic performances in a city. All these city variables come from Places Rated Almanac (Savageau and D'Agostino, 2000).

There is no consensus in the urban literature on the effect of city size on labor productivity. Evidence suggests that agglomeration economies associated with the size of a city raise the productivity of labor and therefore wages (Segal, 1976; Shefer, 1973; Sveikauskas, 1975). On the other hand, Garofalo and Fogarty (1979) assume that larger cities experience net disamenities, therefore skilled labor needs to be compensated to live in larger cities, but not unskilled labor.

\subsection{Model}

We analyze the relationship between our index of IT agglomeration and average wages for college-educated and non-college-educated workers across cities by using a twolevel hierarchical linear model (HLM) to control both for individual and for city variables that also affect wages.

The first level of our model calculates adjusted individual wages for workers with and without a college degree (that is, after controlling for an individual's observable characteristics). The first level of the model is represented by:

$$
\ln W_{i j}=\beta_{0 j}+\beta_{1 j} E_{i j}+\boldsymbol{X}_{i j} \boldsymbol{\theta}+\varepsilon_{i j} \text {. }
$$

We measure workers' productivity by their wages as predicted by economic theory. $\operatorname{Ln} W_{i j}$ is the natural logarithm of annual wage and salary earnings divided by the product of weeks worked and usual weekly hours. ${ }^{(8)}$ The elements of the vector of observed individual characteristics $\left(\boldsymbol{X}_{i j}\right)$ are the traditional variables that affect wages identified by the human capital theory in labor economics (whose effects are assumed to be fixed across cities): the level of experience (measured by age - years of schooling - 6), race, gender, marital status, occupation, school enrollment, disability, and high-tech industry employment. $\boldsymbol{\theta}$ is a vector of the coefficients for observed human characteristic variables. $E_{i j}$ is a binary education variable that is 1 if the individual $i$ in city $j$ does not have a college degree and 0 otherwise. $\beta_{1 j}$ is a randomly varying coefficient for each city $j$ associated with the variable $E$. Thus, the excluded category is college graduate, and its effect is captured by $\beta_{0 j}$ for each city $j$. $\beta_{0 j}$ represents returns to college-educated workers, and $\beta_{1 j}$ represents wage gaps measured by the log difference

(7) Many studies have found that warmer climates are correlated with a willingness to accept lower wages (Cropper, 1981; Gyourko and Tracy, 1991; Roback, 1982, 1988).

(8) To estimate wage equations, labor economists frequently use log wage instead of wages alone as the independent variable. Why? The assumption is that the relationship between education and wages is exponential (not linear). This means that one extra year of education will have a larger effect on wages for workers with a lot of years of education (for example, college degree) than for workers with very few years of education (for example, less than high school). 
between the hourly wages for college graduates $\left(\beta_{0 j}\right)$ and the hourly wages of noncollege graduates, respectively, for each city $j$. The individual error term, $\varepsilon_{i j}$, captures the effects of unobserved individual characteristics and satisfies all the properties of the classical regression model. In particular, $\varepsilon_{i j} \sim \mathrm{N}\left(0, \sigma_{\varepsilon}^{2}\right)$.

In the second level, we estimate the effect of IT agglomeration on variation across cities in the hourly wages of the college-educated worker $\left(\beta_{0 j}\right)$ and in the wage gap between the college-educated and non-college-educated worker $\left(\beta_{1 j}\right)$ :

$$
\begin{aligned}
& \beta_{0 j}=\gamma_{00}+\gamma_{01} E_{j}+\gamma_{02} P_{j}+\gamma_{03} I_{j}+\boldsymbol{S}_{j} \boldsymbol{\eta}_{0}+\boldsymbol{R}_{j} \boldsymbol{\tau}_{0}+v_{0 j}, \\
& \beta_{1 j}=\gamma_{10}+\gamma_{11} E_{j}+\gamma_{12} P_{j}+\gamma_{13} I_{j}+\boldsymbol{S}_{j} \boldsymbol{\eta}_{0}+\boldsymbol{R}_{j} \boldsymbol{\tau}_{0}+v_{1 j} .
\end{aligned}
$$

Observed city characteristics include variables measuring exogenous amenities of the city as well as those measuring productivity-enhancing effects caused by the city's stock of knowledge and accumulation of IT workers. $E_{j}$ represents a city's average level of education, ${ }^{(9)} P_{j}$ represents a city's average level of experience; $I_{j}$ is a city's IT-agglomeration index; $\boldsymbol{S}_{j}$ is the vector of variables that control for the effect of city exogenous amenities that previous studies have suggested are the main sources of urban wage differences. In particular, $\boldsymbol{S}_{j}$ is comprised of a city's art and climate scores and proximity to a coast. Also, $\boldsymbol{\eta}_{0}$ is a vector of the coefficients for $\boldsymbol{S}_{j}$. $\boldsymbol{R}_{j}$ is the vector of three binary variables defining the region of each city: Northeast, Midwest, West. The South is excluded to control for the effect of unobserved region-specific factors that affect wage gaps. Also, $\boldsymbol{\tau}_{0}$ is a vector of the coefficients for $\boldsymbol{R}_{j}$, and $v_{0 j}$ and $v_{1 j}$ are error terms that capture the effects of unobserved city characteristics and that satisfy the properties of the classical regression model. Moreover, the model assumes that both levels have error terms that are uncorrelated across levels.

The fixed coefficients $\gamma_{03}$ and $\gamma_{13}$ represent the effect of a city's IT agglomeration on the portion of wages remaining after controlling for the distribution of observable characteristics within cities. The importance of these fixed coefficients is that their statistical significance and their positive sign test the hypothesis that returns to the skilled (college-educated) and low-skilled (non-college-educated) workers would increase in cities with a greater level of IT agglomeration.

\subsection{Results-IT agglomerations and wages}

The results of the multilevel analysis are shown in table 2. Because they are the only individual-level effects permitted to vary across cities, we reported coefficients only for the intercept and the variable that identifies whether or not a worker has a college degree. Similarly, at the city level (level 2), the coefficients are reported for the intercept, average level of education in the city, average level of experience in the city, and the IT-agglomeration index, for their effects on the intercept and on the individual-level college coefficient.

We began with a model that includes no predictors at either the individual or city levels. This model is equivalent to a one-way ANOVA, which expresses variation in the outcome variable as the sum of the estimated grand mean in the population $\left(\gamma_{00}\right)$, a level-1 random effect $\left(\varepsilon_{i j}\right)$, and a level-2 random effect $\left(v_{0 j}\right)$. This model allows the variability in the outcome variable to be decomposed into within-group and between-group components and is a useful starting point for a multilevel analysis

(9) It is common in this kind of study to use the same variable at both levels; Raudenbush and Bryk (2002) present multiple examples of this case. We would like to highlight their example on pages $119-120$, where they measure the effect of individual and school variables on students' math achievement using the SES (a proxy for social class for the student) at level 1 and average SES (average of social class of students within a school) at level 2. This is in accordance with the assumption of HLM of complete independence of errors across levels. 
Table 2. Hierarchical linear regression results for log wages on individual-level and city-level characteristics.

\begin{tabular}{|c|c|c|c|c|c|}
\hline Variable & Model 1 & Model 2 & Model 3 & Model 4 & Model $5^{\mathrm{a}}$ \\
\hline \multicolumn{6}{|l|}{ Intercept $\left(\beta_{0}\right)$} \\
\hline intercept $\left(\gamma_{00}\right)$ & $2.654 * * *$ & $2.316^{* * *}$ & $1.089 * *$ & $1.136^{* *}$ & $1.017 * * *$ \\
\hline MSA education $\left(\gamma_{01}\right)$ & & & $0.051 * *$ & $0.034 *$ & $0.044 * *$ \\
\hline MSA experience $\left(\gamma_{02}\right)$ & & & 0.015 & $0.027 * * *$ & $0.027 * * *$ \\
\hline IT agglomeration $\left(\gamma_{03}\right)$ & & & & $0.033 * * *$ & $0.029 * * *$ \\
\hline controls & none & level 1 & all & all & all \\
\hline \multicolumn{6}{|l|}{ Non-college educated $\left(\beta_{1}\right)$} \\
\hline intercept $\left(\gamma_{10}\right)$ & & $-0.332 * * *$ & $-1.240 * * *$ & $-1.263 * * *$ & $-1.219^{* * *}$ \\
\hline MSA education $\left(\gamma_{11}\right)$ & & & $0.055^{* * *}$ & $0.064 * * *$ & $0.061 * * *$ \\
\hline MSA experience $\left(\gamma_{12}\right)$ & & & 0.011 & 0.004 & 0.004 \\
\hline IT agglomeration $\left(\gamma_{13}\right)$ & & & & $-0.017 * * *$ & $-0.016 * * *$ \\
\hline \multicolumn{6}{|l|}{ Variance components } \\
\hline level-1 variance $\left(\sigma^{2}\right)$ & 0.429 & 0.290 & 0.290 & 0.290 & 0.290 \\
\hline intercept $\left(\tau_{00}\right)$ & 0.018 & 0.010 & 0.006 & 0.004 & 0.004 \\
\hline slope $\left(\tau_{11}\right)$ & & 0.004 & 0.002 & 0.002 & 0.002 \\
\hline
\end{tabular}

*** $p<0.001, * * p<0.05, * p<0.10$.

a Model 5 includes metro area population as a control variable.

(Raudenbush and Bryk, 2002). Specifically, the variance of $Y_{i j}$ is equal to $\tau_{00}+\sigma^{2}$, where $\tau_{00}=\operatorname{var}\left(v_{0 j}\right)$, which yields the between-group variability, and $\sigma^{2}=\operatorname{var}\left(\varepsilon_{i j}\right)$, the within-group variability. The variance components $\tau_{00}$ and $\sigma^{2}$ can be used to form the intraclass correlation coefficient $(\rho)$, which yields the proportion of the variance in the outcome variable that exists between the level-2 units. It is computed as $\rho=\tau_{00} \div\left(\tau_{00}+\sigma^{2}\right)$. From model $1, \rho$ suggests that approximately $4 \%$ of the total variability in wages is due to differences across cities, while $96 \%$ is attributable to wage differences across individuals.

Model 2 includes only the individual-level controls. Although we do not present results for the level-2 variables, we would note that all are significant at the $1 \%$ level and have the expected signs. The intercept in this model $(2.316$, or $\$ 10.13)$ represents the predicted hourly wage for a full-time worker with value zero in the control dummy variables. Net of the individual-level controls, wages for non-college-educated full-time workers are predicted to be significantly less $(2.316-0.332=1.979$, or $\$ 7.27)$. Thus, adjusting for college-education differences in the individual controls, hourly wages for non-college-educated workers are approximately $71 \%$ of college-educated workers' wages.

Model 3 includes controls at level 1 and level 2. It includes the effect of the city's average level of education and experience on the model intercept and the individuallevel college variable. As in Rauch's (1993) study, our coefficients for the average level of experience are insignificant. Also, like Rauch (1993), we find a positive and statistically significant coefficient (at least the 5\% level) for the effect of the average level of education in a city on the variability of the wages for college-educated and non-collegeeducated workers across cities. More specifically, our results indicate that increasing the average level of education in the city by one year would increase wages for collegeeducated workers by $5 \%\left(\gamma_{01}\right)$ and for non-college-educated workers by $10 \%\left(\gamma_{01}+\gamma_{11}\right)$. Rauch (1993) estimates that an increase in the average level of education in a US city of one year increases an individual's wages by between $3 \%$ and $4 \%$. However, our estimates are not strictly comparable to his; Rauch calculated the effect of total costs of an additional year of a city's average education on total factor productivity, which 
includes the effects on all factors of production - in his case, land rents and wages. $\mathrm{He}$ also used a different model since he assumed that only the intercept is random. In sum, our results support previous evidence in favor of the average level of human capital as a productive local public good.

Model 4 includes the main effect of our IT-agglomeration index. In this model, we measure whether there is a wage premium for two groups of workers - those with a college degree and those without a college degree - from living in a city with a large concentration of IT workers. It appears that a large accumulation of IT workers reduce the productivity effects associated with average level of education and slightly enhances those associated with the average level of experience for college-educated workers. As expected, the coefficient on the IT index has a positive sign and it is significant at the $1 \%$ level for workers with college education. Our results show that a city's IT agglomeration is also an amenity. Skilled individuals prefer to work in cities with a very large accumulation of IT or educated workers. We speculate that this is because working in such a city gives them access to a larger stock of knowledge which allows them to be more efficient in their job tasks and therefore more productive. However, the effect on non-college-educated workers of living in such a city, although significant, is negative, indicating that the contribution of the IT index to this group of workers is less than for college-educated workers. Indeed, a 1-unit increase in the index will increase wages for college-educated workers by $3.3 \%$, but only by $1.6 \%$ for non-college-educated workers. ${ }^{(10)}$ Our results are in-line with previous studies that measure the effect of the spatial concentration of workers on a region's productivity. Ciccone and Hall (1996), for instance, estimate that doubling employment density in a county increases average labor productivity by $6 \%$.

Results from model 5, which includes the MSA's population as a control variable, show that the coefficient for population, although statistically significant at the $1 \%$ level, is very close to zero, suggesting very small productivity effects associated with city size. ${ }^{(11)}$

\section{Conclusions}

Jobs in the design and customization of IT will increase as more businesses and public organizations use hardware, software, and IT services. Moreover, jobs demanding the high skills required to use these IT packages effectively will diffuse through the economy. However, the globalization of software and IT jobs means that some jobs will be done abroad. Indeed, call-center operations have moved to Ireland and some programming jobs have moved to India. In this paper, we ask: does it matter where IT workers locate? In other words, does it matter that IT workers-both low-skilled (such as operators) and high-skilled (such as programming engineers) - might disappear from US cities?

We maintain here that the economic impact of a possible overseas relocation of IT workers is better understood when we recognize that IT workers are not homogeneously dispersed across metropolitan areas. Rather, they tend to concentrate in relatively few cities and to account for a much larger proportion of the local market than we observe for the country as whole. Using data from the 2000 Census of Population, we find that 20 of the 100 largest metropolitan areas in the United States have 33\% of the IT workers in our sample of 1.4 million full-time workers. Moreover, while IT workers account for only $7 \%$ of the total sample, they have a much larger weight in

(10) For the college-educated workers: $\partial \ln W_{i j} / \partial I_{j}=\gamma_{03}$. For the non-college-educated workers: $\partial \ln W_{i j} / \partial I_{j}=\gamma_{03}+\gamma_{13}$.

(11) There is not significant correlation among level-2 variables. 
local markets (metropolitan areas): IT workers account for $18 \%$ in San Jose and about $12 \%$ in Middlesex, New Jersey, and $11 \%$ in Washington, DC. These statistics point toward a relatively high impact in cities with a large concentration of IT workers, which are usually the more vibrant economic and political metropolises.

Moreover, we find that workers in cities with a large concentration of IT workers enjoy productivity-enhancing effects. Results from our hierarchical linear models (which allow us to control both for individual-level and for city-level variables that affect wages) show that both college-educated and non-college-educated workers tend to have higher wages in cities where there is a large concentration of IT workers. These gains are larger for college-educated workers than for those without a college degree. The large concentration of both high-skilled and low-skilled IT workers has positive effects on the wages of local workers. These results support the view that the productivity of workers in these cities will decline if either (or both) high-skilled and low-skilled IT jobs move overseas. ${ }^{(12)}$ Our models do not allow us to explain why or how the agglomeration of IT workers is associated with a wage premium after controlling for individual and city variables that also affect wages. But we speculate that if significant numbers of these clustered IT jobs were offshored, productivity and its attendant wage premium would deteriorate because of the loss of high-skilled IT workers' knowledge spillovers and the loss of the benefits from medium-skilled and low-skilled IT workers running a more efficient IT infrastructure.

Are cities dying? Is IT rapidly making the need for face-to-face contact-and thus the need for cities - obsolete? We propose here that any analysis of the effect of IT on cities should be conducted under the assumption that IT comes in a package: hardware, software, and business services (IT workers). This concept recognizes that making IT hardware fit for an organization comes in part from increasing software and ITservice components of the IT package. In this regard, policy makers analyzing the effect of IT on the future of cities need to take into consideration not only the impact of IT hardware (for example, computers), as has traditionally been done, but also the impact of IT human capital because, as we have shown in this paper, the location of IT workers does matter.

Acknowledgements. This material is based upon work supported by the National Science Foundation under Grant No. 0318174. Any opinions, findings, and conclusions or recommendations expressed in this material are those of the authors and do not necessarily reflect the views of the National Science Foundation. The support of the Bureau of Business Research at the University of Texas is greatly appreciated. This article was improved by the constructive comments of three referees.

\section{References}

Applegate L, Cash J, Mills D Q, 1988, “Information technology and tomorrow's manager" Harvard Business Review 66(6) 128 - 136

Audretsch D B, Feldman M P, 1996, "R\&D spillovers and the geography of innovations and production" American Economic Review 86630 - 640

Autor D H, Katz L F, Krueger A B, 1998, "Computing inequality: have computers changed the labor market?" Quarterly Journal of Economics 1131169 - 1214

Black D, Henderson V, 1999, "A theory of urban growth" Journal of Political Economy 107252 - 284

Black S, Lynch L, 2001, "How to compete: the impact of workplace practices and information technology on productivity" Review of Economics and Statistics $83434-445$

Bresnahan T, Brynjolfsson E, Hitt L, 2002, "Information technology, workplace organization, and demand for skilled labor: firm-level evidence" Quarterly Journal of Economics 117339 - 376

Brynjolfsson E, Hitt L, 1996, "Paradox lost? Firm-level evidence on the returns to information systems spending" Management Science 42541 - 558

Brynjolfsson E, Hitt L M, 2003, "Computing productivity: firm-level evidence" The Review of Economics and Statistics $85793-808$

Cairncross F, 1997 The Death of Distance (Harvard Business School Press, Boston, MA) 
Card D, Dinardo J E, 2002, “Technology and US wage inequality: a brief look” Economic Review Federal Reserve Bank of Atlanta 87(3) $45-62$

Chapple K, Markusen A, Schrock G, Yamamoto D, Yu P, 2004, "Gauging metropolitan 'high-tech' and 'I-tech' activity" Economic Development Quarterly 8 10-29

Ciccone A, Hall R, 1996, "Productivity and the density of economic activity" American Economic Review 86 54-70

Cooke S D, 2002, "Jobs in the new economy", in Digital Economy 2002 US Department of Commerce, Economics and Statistics Administration, Washington, DC, pp $41-50$

Cropper M L, 1981, "The value of urban amenities" Journal of Regional Science 21 359-374

Daveri F, 2003, "Information technology and productivity growth across countries and sectors", WP 227, Innocenzo Gasparini Institute for Economic Research, Bocconi University, Milan, http://ssrn.com/abstract $=371583$

DeVol R, 1999 America's High-tech Economy: Growth, Development, and Risks for Metropolitan Areas (Milken Institute, Santa Monica, CA)

Doms M, Dunne T, Troske K, 1997, "Workers, wages, and technology" Quarterly Journal of Economics $112253-290$

Eaton J, Eckstein Z, 1997, "Cities and growth: theory and evidence from France and Japan" Regional Science and Urban Economics 27443 - 474

Garofalo G, Fogarty M S, 1979, "Urban income distribution and the urban hierarchy-equality hypothesis" Review of Economics and Statistics 61381 - 388

Gereffi G, Sturgeon T J, 2004, "Globalization, employment, and economic development: a briefing paper", WP 04-006, Industrial Performance Center, Massachusetts Institute of Technology, Cambridge, MA, http://web.mit.edu/ipc/www/pubs/articles/IPC04-006.pdf

Glaeser E L, Mare D C, 1994, "Cities and skills", WP 4728, National Bureau of Economic Research, Cambridge, MA

Goodchild M F, 2001, "Towards a location theory of distributed computing and e-commerce", in Worlds of Electronic Commerce: Economic, Geographical, and Social Dimensions Eds T R Leinbach, S D Brunn (John Wiley, New York) pp 67-86

Gubarxani V, Kraemer K, Vitalari N, 1997, "Note: an economic analysis of IS budget” Management Science $\mathbf{4 3} 1745$ - 1755

Gyourko J, Tracy J, 1991, "The structure of local public finance and the quality of life" Journal of Political Economy $99774-806$

Haas P M, 1992, "Introduction: epistemic communities and international policy coordination" International Organization 461 - 35

Hagedoorn J, 2002, "Inter-firm R\&D partnerships: an overview of major trends and patterns since 1960" Research Policy 31477 - 492

Hecker D, 1999, "High-technology employment: a broader view" Monthly Labor Review 122(6) $18-28$

Hitt L, Brynjolfsson E, 1995, "Creating value and destroying profits? Three measures of information technology's contributions", WP 183, Center for Coordination Science, Sloan School, Massachusetts Institute of Technology, Cambridge, MA

Josefek R A, Kauffman R J, 1998, "Duration of IT human capital employment", submitted to the 10th Workshop on Information Systems and Economics, New York, http://is-2.stern.nyu.edu/ $\sim$ wise98/pdf/seven_b.pdf

Kotkin J, 2000 The New Geography: How the Digital Revolution is Reshaping the American Landscape (Random House, New York)

Krueger A, 1993, "How computers have changed the wage structure: evidence from Microdata, 1984 - 1989" Quarterly Journal of Economics 108(1) 33-60

Lavoie D, 2004, "Subjectivism, entrepreneurship, and the convergence of groupware and hypertext", in Markets, Information, and Communication-Austrian Perspectives on the Internet Economy Eds J Birner, P Garrouste (Routledge, New York) pp 21 - 46

Leamer E E, Storper M, 2001, “Economic geography of the Internet age”, WP 8450, National Bureau of Economic Research, Cambridge, MA

Lichtenberg F R, 1993, "The output contributions of computer equipment and personnel: a firm-level analysis", WP 4540, National Bureau of Economic Research, Cambridge, MA

Lynne M, Marcus R B, 1997, "The magic bullet theory in IT-enabled transformation" Sloan Management Review 38(2) 55-68

McDermott R, 1999, "Why information technology inspired but cannot deliver knowledge management" California Management Review 41(4) 103-117 
Mann C L, 2003, "Globalization of IT services and white collar jobs: the next wave of productivity growth", WP PB03-11, Institute for International Economics, Washington, DC

NSF, 2001 Research and Development in Industry: 1999, Early Release Tables (National Science Foundation, Arlington, VA)

NSF, 2002 Science and Engineering Indicators-2002 NSB 02-01 (National Science Foundation, Arlington, VA)

Ozer M, 2000, "Information technology and new product development: opportunities and pitfalls" Industrial Marketing Management 29387 - 396

Rallet A, Torre A, 1998, "On geography and technology: proximity relations in localised innovation networks", in Clusters and Regional Specialisation: On Geography, Technology, and Networks Ed. M.Steiner (Pion, London) pp $41-56$

Rauch J, 1993, "Productivity gains from geographic concentration of human capital: evidence from the cities" Journal of Urban Economics 34380 - 400

Raudenbush S W, Bryk A S, 2002 Hierarchical Linear Models-Applications and Data Analysis Methods 2nd edition (Sage, Thousand Oaks, CA)

Roback J, 1982, "Wages, rents, and the quality of life" Journal of Political Economy 901257 - 1278

Roback J, 1988, "Wages, rents, and amenities: differences among workers and regions" Economic Inquiry 26(1) $23-41$

Savageau D, D’Agostino R, 2000 Places Rated Almanac millennium edition (IDG Books, Foster City, CA)

Segal D, 1976, “Are there returns to scale in city size?" Review of Economics and Statistics $\mathbf{5 8}$ $339-350$

Shefer D, 1973, "Localization economies in SMSAs: a production function approach" Journal of Regional Science $1355-64$

Storper M, Venables A J, 2004, "Buzz: face-to-face contact and the urban economy" Journal of Economic Geography 4351 - 370

Sveikauskas L, 1975, “The productivity of cities" Quarterly Journal of Economics 89393 - 413

USDC, 1997, "Economy-wide and industry-level impact of information technology", ESA/ OPD 97-3, US Department of Commerce, Economic and Statistics Administration, Office of Policy Development, https://www.esa.doc.gov/reports/economy-wide.pdf

USDC, 2002 Digital Economy 2002 US Department of Commerce, Economics and Statistics Administration, Washington, DC, https://www.esa.doc.gov/2002.cfm

Valleta R, MacDonald G, 2004, “The computer evolution” Federal Reserve Bank of San Francisco Economic Letter July, $1-4$

Wenger E, McDermott R, Snyder W M, 2002 Cultivating Communities of Practice (Harvard Business School Press, Cambridge, MA)

Wheeler C H, 2005a, "Evidence on wage inequality, worker education, and technology" Federal Reserve Bank of St. Louis Review May/June, 375 - 393

Wheeler C H, 2005b, "Technology and industrial agglomeration: evidence from computer usage", WP 2005-016A, Federal Reserve Bank of St. Louis, MO 


\section{Appendix}

Table A1. Information technology (IT)-related occupations (source: USDC, 2002).

\section{OES code Occupational title}

\section{High skilled}

11-9041 Engineering managers

11-3021 Computer and information systems managers

15-1011 Computer and information scientists, research

15-1021 Computer programmers

15-1031 Computer software engineers, applications

15-1032 Computer software engineers, systems

15-1041 Computer support specialists

15-1051 Computer systems analysts

15-1061 Database administrators

15-1071 Network and computer systems administrators

15-1081 Network systems and data communications analysts

17-2061 Computer hardware engineers

17-2071 Electrical engineers

17-2072 Electronics engineers, except computer

17-3023 Electrical and electronic engineering technicians

\section{Moderately skilled}

43-9021 Data entry keyers

49-2011 Computer, automated teller, and office machine repairers

49-2022 Telecommunications equipment installers and repairers, except line installers

49-2094 Electrical and electronics repairers, commercial and industrial equipment repairers

49-9051 Electrical power-line installers and repairers

49-9052 Telecommunication line installers and repairers

51-2022 Electrical and electronic equipment assemblers

51-2023 Electromechanical equipment assemblers

51-9141 Semiconductor processors

\section{Low skilled}

43-2011

43-2021

43-3021

43-9011

43-9051

Switchboard operators, including answering service

Telephone operators

Billing and posting clerks and machine operators

Computer operators

Mail clerks and mail machine operators, except postal service 
Table A2. IT (information technology) agglomeration index by metro area, all skill levels.

\begin{tabular}{|c|c|c|c|c|c|c|c|c|}
\hline Rank & Metro area & Index & Rank & Metro area & Index & Rank & Metro area & Index \\
\hline 1 & Washington, DC-MD-VA-WV & 8.850 & 37 & Norfolk-Virginia Beach-Newport & 0.777 & 69 & Tucson, AZ & 0.311 \\
\hline 2 & San Jose, CA & 7.840 & & News, VA-NC & & 70 & Tulsa, OK & 0.292 \\
\hline 3 & Chicago, IL & 4.739 & 38 & Cincinnati, OH-KY-IN & 0.719 & 71 & Ann Arbor, MI & 0.291 \\
\hline 4 & Dallas, TX & 3.859 & 39 & Orlando, FL & 0.714 & 72 & Buffalo-Niagara Falls, NY & 0.285 \\
\hline 5 & Boston, MA-NH & 3.790 & 40 & Rochester, NY & 0.711 & 73 & Columbia, SC & 0.248 \\
\hline 6 & New York, NY & 3.387 & 41 & Richmond-Petersburg, VA & 0.695 & 74 & Akron, $\mathrm{OH}$ & 0.246 \\
\hline 7 & Los Angeles-Long Beach, CA & 3.268 & 42 & Charlotte-Gastonia-Rock Hill, & 0.660 & 75 & Honolulu, HI & 0.243 \\
\hline 8 & Atlanta, GA & 3.159 & & $\mathrm{NC}-\mathrm{SC}$ & & 76 & Las Vegas, $\mathrm{NV}-\mathrm{AZ}$ & 0.228 \\
\hline 9 & Oakland, CA & 3.117 & 43 & Salt Lake City-Ogden, UT & 0.658 & 77 & Grand Rapids-Muskegon-Holland, & 0.224 \\
\hline 10 & Philadelphia, PA-NJ & 2.719 & 44 & Riverside-San Bernardino, CA & 0.633 & & MI & \\
\hline 11 & Seattle-Bellevue-Everett, WA & 2.634 & 45 & Milwaukee-Waukesha, WI & 0.615 & 78 & Tacoma, WA & 0.222 \\
\hline \multirow[t]{2}{*}{12} & Middlesex-Somerset-Hunterdon, & 2.322 & 46 & Indianapolis, IN & 0.614 & 79 & Allentown-Bethlehem-Easton, PA & 0.219 \\
\hline & NJ & & 47 & Jacksonville, FL & 0.604 & 80 & New Orleans, LA & 0.205 \\
\hline 13 & Denver, CO & 2.247 & 48 & Fort Lauderdale, FL & 0.601 & 81 & Scranton-Wilkes-Barre-Hazleton, & 0.199 \\
\hline 14 & Baltimore, MD & 2.138 & 49 & Albany-Schenectady-Troy, NY & 0.583 & & PA & \\
\hline 15 & San Francisco, CA & 2.094 & 50 & San Antonio, TX & 0.546 & 82 & Greenville-Spartanburg-Anderson, & 0.194 \\
\hline 16 & Phoenix-Mesa, AZ & 2.060 & 51 & Nashville, TN & 0.514 & & SC & \\
\hline 17 & Minneapolis-St. Paul, MN-WI & 2.034 & 52 & Hartford, CT & 0.494 & 83 & Springfield, MA & 0.178 \\
\hline 18 & Raleigh-Durham-Chapel Hill, NC & 2.033 & 53 & Louisville, KY-IN & 0.474 & 84 & Knoxville, TN & 0.167 \\
\hline 19 & Orange County, CA & 1.913 & 54 & Ventura, CA & 0.458 & 85 & Vallejo-Fairfield-Napa, CA & 0.163 \\
\hline 20 & Houston, TX & 1.843 & 55 & Greensboro-Winston-Salem - & 0.452 & 86 & New Haven - Meriden, CT & 0.162 \\
\hline 21 & Austin-San Marcos, TX & 1.838 & & High Point, NC & & 87 & Little Rock-North Little Rock, AR & 0.149 \\
\hline 22 & San Diego, CA & 1.836 & 56 & Omaha, NE-IA & 0.427 & 88 & Stockton-Lodi, CA & 0.135 \\
\hline 23 & Detroit, MI & 1.734 & 57 & Dayton-Springfield, $\mathrm{OH}$ & 0.422 & 89 & Wichita, KS & 0.128 \\
\hline 24 & Newark, NJ & 1.625 & 58 & Providence-Fall River- & 0.418 & 90 & Toledo, $\mathrm{OH}$ & 0.124 \\
\hline 25 & Sacramento, CA & 1.389 & & Warwick, RI-MA & & 91 & Gary, IN & 0.107 \\
\hline \multirow[t]{2}{*}{26} & Tampa-St. Petersburg-Clearwater, & 1.246 & 59 & Jersey City, NJ & 0.405 & 92 & El Paso, TX & 0.103 \\
\hline & FL & & 60 & Miami, FL & 0.398 & 93 & Sarasota-Bradenton, FL & 0.095 \\
\hline 27 & St. Lousi, MO-IL & 1.244 & 61 & Harrisburg-Lebanon-Carlisle, & 0.392 & 94 & Charleston-North Charleston, SC & 0.094 \\
\hline 28 & Nassau-Suffolk, NY & 1.236 & & PA & & 95 & Baton Rouge, LA & 0.094 \\
\hline 29 & Columbus, OH & 1.160 & 62 & Memphis, $\mathrm{TN}-\mathrm{AR}-\mathrm{MS}$ & 0.389 & 96 & Fresno, CA & 0.093 \\
\hline 30 & Portland-Vancouver, OR-WA & 1.129 & 63 & Birmingham, AL & 0.387 & 97 & Bakersfield, CA & 0.077 \\
\hline 31 & Fort Worth-Arlington, TX & 1.113 & 64 & Wilmington-Newark, DE-MD & 0.363 & 98 & Mobile, AL & 0.076 \\
\hline 32 & Kansas City, MO-KS & 1.078 & 65 & West Palm Beach-Boca Raton, & 0.338 & 99 & Youngstown-Warren, $\mathrm{OH}$ & 0.071 \\
\hline 33 & Bergen-Passaic, NJ & 0.923 & & FL & & 100 & McAllen-Edinburg-Mission, TX & 0.022 \\
\hline 34 & Cleveland-Lorain-Elyria, $\mathrm{OH}$ & 0.915 & 66 & Oklahoma City, OK & 0.337 & & & \\
\hline 35 & Monmouth-Ocean, NJ & 0.850 & 67 & Syracuse, NY & 0.325 & & & \\
\hline 36 & Pittsburgh, PA & 0.830 & 68 & Albuquerque, NM & 0.317 & & & \\
\hline
\end{tabular}


Table A3. Percentage of IT (information technology) workers by metro area.

San Jose, CA

$\begin{array}{ll}\text { San Jose, CA } & 17.79 \\ \text { Middlesex-Somerset-Hunterdon, } & 11.78\end{array}$

Middlesex - Somerset-Hunterdon,

$$
\text { NJ }
$$

Washington, DC-MD-VA-WV

Austin-San Marcos, TX

Oakland, CA

San Francisco, CA

Denver, CO

Boston, MA-NH

Seattle-Bellevue-Everett, WA

Dallas, TX

Omaha, NE-IA

Minneapolis-St. Paul, MN-WI

Sacramento, CA

Baltimore, MD

Monmouth-Ocean, NJ

Atlanta, GA

Columbus, $\mathrm{OH}$

Bergen-Passaic, NJ

Jersey City, NJ

Rochester, NY

Ann Arbor, M

Newark, NJ

Kansas City, MO-KS

Wilmington-Newark, DE-MD

Fort Worth-Arlington, TX

San Diego, CA

Hartford, CT

Portland-Vancouver, OR-WA

Phoenix - Mesa, AZ

Philadelphia, PA - NJ

Orange County, CA

Chicago, IL

Albany-Schenectady-Troy, NY

Tulsa, OK

Harrisburg-Lebanon-Carlisle, PA

Ventura, CA

$\begin{array}{r}17.79 \\ 11.78 \\ 11.33 \\ 10.56 \\ 10.53 \\ 10.26 \\ 9.58 \\ 9.42 \\ 9.28 \\ 9.23 \\ 8.98 \\ 8.42 \\ 8.42 \\ 8.29 \\ 8.01 \\ 7.95 \\ 7.78 \\ 7.73 \\ 7.54 \\ 7.47 \\ 7.46 \\ 7.45 \\ 7.43 \\ 7.38 \\ 7.38 \\ 7.35 \\ 7.35 \\ 7.31 \\ 7.21 \\ 7.14 \\ 7.09 \\ 7.06 \\ 7.05 \\ 7.00 \\ 6.95 \\ 6.92 \\ 6.76 \\ \\ \hline\end{array}$

38

Tampa-St. Petersburg-

Clearwater, FL

St. Louis, MO-IL

Richmond-Petersburg, VA

Salt Lake City-Ogden, UT

Milwaukee-Waukesha, WI

Cincinnati, $\mathrm{OH}-\mathrm{KY}-\mathrm{IN}$

Birmingham, AL

Jacksonville, FL

Albuquerque, NM

New Haven-Meriden, CT

Tucson, AZ

Houston, TX

Norfolk - Virginia Beach-

Newport News, VA-NC

Columbia, SC

Detroit, MI

(\%)

Charlotte-Gastonia-Rock Hill,

$$
\mathrm{NC}-\mathrm{SC}
$$

Louisville, $\mathrm{KY}-\mathrm{IN}$

Dayton-Springfield, $\mathrm{OH}$

Indianapolis, IN

New York, NY

Nassau-Suffolk, NY

Oklahoma City, OK

Pittsburgh, PA

Memphis, TN-AR-MS

Allentown-Bethlehem-Easton, PA

Nashville, TN

Fort Lauderdale, FL

Cleveland-Lorain-Elyria, $\mathrm{OH}$

Orlando, FL

San Antonio, TX

\begin{tabular}{l}
5.56 \\
\hline
\end{tabular}

Providence-Fall River-Warwick, 5.48

RI-MA

69
6.71

6.69

6.59

6.50

6.42

6.30

6.29

6.27

6.19

6.11

6.06

6.06

6.02

6.01

6.01

5.98

5.95
5.95
5.85

.78

5.74

5.73

5.71

5.68

5.56
5.48

5.44

West Palm Beach-Boca Raton, FL $\quad 5.35$

\section{Akron, $\mathrm{OH}$}

Syracuse, NY

ton - Salem -

ittle Rock-North Little Rock, AR 5.03

Vallejo-Fairfield-Napa, CA $\quad 5.02$

Springfield, MA $\quad 4.94$

Springfield, MA

Grand Rapids-Muskegon-Holland, $\quad 4.82$

MI

Scranton-Wilkes-Barre-Hazleton, 4.81

$$
\text { PA }
$$

Tacoma, WA

Buffalo-Niagara Falls, NY

Wichita, KS

Stockton-Lodi, CA

Honolulu, HI

Greenville - Spartanburg-

$$
\text { Anderson, SC }
$$

Riverside-San Bernardino, CA

New Orleans, LA

Toledo, $\mathrm{OH}$

Bakersfield, CA

Gary, IN

Mobile, AL

Miami, FL

Charleston-North Charleston, SC

Sarasota-Bradenton, FL

Baton Rouge, LA

El Paso, TX

Las Vegas, NV-AZ

Youngstown-Warren, $\mathrm{OH}$

Fresno, CA

McAllen-Edinburg-Mission, TX 
Conditions of use. This article may be downloaded from the E\&P website for personal research by members of subscribing organisations. This PDF may not be placed on any website (or other online distribution system) without permission of the publisher. 